\title{
Milo Urban's Journalist Writing and Memoirs on the Theme of the Holocaust (in Slovak literature)
}

\begin{abstract}
Csiba Karol, Milo Urban's Journalist Writing and Memoirs on the Theme of the Holocaust (in Slovak literature). "Poznańskie Studia Slawistyczne" 12. Poznań 2017. Publishing House of the Poznań Society for the Advancement of the Arts and Sciences, pp. 47-60. ISSN 2084-3011.

The article discusses selected texts of different genres by Milo Urban (1904-1982). The first text level is represented by fragments from his memoirs written in the 1970s and only published in the 1990s. An analysis of Urban's journalistic activities during the Second World War provides us with another point of view. The article wishes to show different language versions elaborated by one author when dealing with one particular historical moment (the solution of the Jewish question and the Holocaust). This points at a significant change in Urban's attitude to historical tragedies of the $20^{\text {th }}$ century, and raises the question about a personal tragedy of an individual as well as his ability to cope with guilt and responsibility.
\end{abstract}

KeYwords: memoirs; journalism; confrontations; the Jewish question; daily "Gardista" (Guard Member); author's subject; author; Holocaust; Milo Urban

The article wishes to find answers to the question, in which way memoirs and journalist writing of an important Slovak fiction writer ${ }^{1}$

\footnotetext{
1 "Milo Urban (1904-1982) - writer and journalist (...). He worked in the newspaper Slovák (Slovak) which was an official daily of Hlinka's Slovak Folk Party (HSL'S, Hlinkova slovenská l'udová strana). In his literary activities, he showed strong social feelings, which brought him close to a left-wing group DAV in the interwar period. Later, the ideology of the Folk Party, which united social and nationalist elements prevailed in his thought. His attitude, originally of a man of literature and non-political, changed after 1940 when he became the editor-in-chief of the newspaper "Gardista" (Guard Member), which represented opinions of a radical National Socialist wing of the HSLS led by Alexander Mach. He was the editor-in-chief until 1945 and the end of the Slovak Republic (...) After having been interned in Bavaria and handed over to Czechoslovak authorities, he was tried in court and «publically
} 
and journalist are related to the key issue - to the theme of the Holocaust (which is only raised vaguely at this point). A rather broad theme will be significantly narrowed by presenting a set of material notes discussing fragments of autobiographical texts. Another approach will focus on activities of this writer as an editor and journalist working in a daily periodical "Gardista" (Guard Member) ${ }^{2}$, carried out in a rather short period - this line of reasoning will offer us parallel references. I will discuss several newspaper articles published between 1940 and 1945. Dictionary entries and explanations used in the article will provide us with the historical context; and these are void of judgement or evaluation aspect. Instead, I often quote original statements and sources. I believe that this sort of perception - focused on "writing" by one author that combines genres - will show us the extent of his participation in creating reasons and forming, and eventually "carrying out" one of the $20^{\text {th }}$ century biggest tragedies. Considering the central theme, my article is the first attempt to confront memoirs and journalism by Milo Urban. I focus on differences and discrepancies in the perception of the Holocaust in two different genres written by the same author. I deliberately do not deal with broader historical circumstances; I also do not compare Milo Urban's position with other writers, and I do not develop current research of the Holocaust in other contexts and other areas of humanities.

Milo Urban dedicates the third book of his memoirs Na brehu krvavej rieky (On the Blood River Bank, 1994) to the period when he was the editor-in-chief of the daily "Gardista". He describes in details last days of

reprimanded». He continued his literary activities" (Lukáč 1997: 539). All translations from Slovak in the text and footnotes are mine.

I would like to mention that in 1940, Urban publishes his novel V osidlach (In Nets), and in 1957, a novel Zhasnuté svetlá (Lights Switched Off), in which he refers to the period of the Second World War in Slovakia.

I emphasize the fact that Milo Urban is currently considered one of the most remarkable Slovak fiction writers; one of the generation that modernized Slovak fiction in the interwar period. In spite of his activities in favour of the political regime of the autonomous Slovak Republic during the Second World War, which was ideologically and racially extreme, Urban's works belong to recommended reading on all levels of Slovak schools.

2 "Gardista" was a specialized periodical of the radical and armed part of the HSL'S (Hlinka's Slovak Folk Party) attacking "enemies” (such as Jews, Czechs, Hungarians, Communists, and others). 
October 1940 when he left the "Slovák" (Slovak) in order to start working in the "Gardista" since the latter periodical was to become a daily from November $1,1940^{3}$. He denies that he was driven by ambitions. Instead, he mentions his first radical refusal: "Well no. This was nothing for me. One was expected to dance here and my legs of a gamekeeper... I refused it without thinking" (Urban 1994: 68) ${ }^{4}$. He writes that he changed his opinion when he was offered to take part in removing "vices" of public life and to introduce healthier and, in his words, also more progressive forces. He considers that these reasons, along with a higher salary, were decisive ones, and he adds that seeing his own name printed in majuscules on the front page of the paper caused him neither joy nor pride. Instead, he mentions his own anger and shame for accepting the position of the editor-inchief. He states that he perceived his role as a certain political and ideological trap which, willy-nilly, made him live the life of a vassal with no inner political ambition. In this situation, he chose silence about several moments of life crises as a defence mechanism considering this decision an expression of his innocent pragmatism.

The initial stage of this new life period is characterized in Urban's memoirs by statements confirming his previous reserved reactions to the external social and historical context:

I polished various manuscripts almost furiously so that, at least, my name on the front page of the magazine was no shame for the Slovak language. However, this idyll did not last long. The Prime Minister Dr. Tuka and, along with him, the Home Minister Mach began to haunt me with a spectre of the Jewish question. We... What about us? We could not stop the flow of essays and articles flooding from the Central Directory of Hlinka's Guard, from the Home Ministry and from the Propaganda Office. Almost a grotesque situation occurred not on single occasion. An anti-Jewish article on a desk in front of me and a Jewish person submitting a plea in an armchair for guests (Urban 1994: $70-71)^{5}$.

${ }^{3} \mathrm{I}$ add that Milo Urban took part in the meeting on culture in Tatranská Lomnica on 30 August 1940 that set trends for the ideology of the new state. He wrote an article Naše stanovisko (Our Standpoint), in which he declared that the ideology of Slovak National Socialism had begun with the rise of Slovak autonomy (Csiba 2014a: 336-337).

4 “Nuž nie. Toto nebolo pre mňa. Tu sa žiadalo tancovat' a moje hájnické nohy... Bez rozmýšl'ania som odmietol" (Urban 1994: 68).

5 "Priam zúrivo som apretoval kdejaké rukopisy, aby moje meno na titulnej strane časopisu aspoň slovenčine nerobilo hanbu. Lenže táto idyla netrvala dlho. Predseda vlády dr. Tuka a s ním i minister vnútra Mach začali mátožit’ so židovskou otázkou. My... Čo my? 
Other lines also show how the author as a person coped with challenges of this emotionally difficult period. His statement, however, does not convey emergency. This narrative dimension would probably have expressed tragedy of particular episodes in a more functional way, and would have given narrator a "more unequivocal position" in the process of mediating information. In this relation, the author of the memoirs explains that his verbalized interest to get involved in forming the society back then, characterized by him as "minimal" work, was mostly aimed against two "vices": aryanisators (people of "Aryan" origin who took over property confiscated to Jews) and members of the so-called administrative boards. He specifies this key information when he writes that he was more interested in the latter group of people who fatally (negatively) influenced and abused the development of the state in financial and social terms. The author admits that he was less interested in the problem of aryanisation even though its connection with financial and social situation is quite visible. Katarína Hradská writes about this "historical phenomenon" in her epilogue to the Slovak translation of Wolfgang Benz's book Holocaust (2010):

Similarly to Germany, also in Slovakia, aryanisation of Jewish property and closing down Jewish enterprises meant a significant intervention into lives of individual people and, eventually, of the whole Jewish community. The state legally - by aryanisation - deprived owners of Jewish enterprises of their property, which went to "Christian hands". Jews exposed to aryanisation remained without any income, lost their work

Nemohli sme zastavit' príval úvah a článkov, valiacich sa z HVHG, z ministerstva vnútra a z úradu propagandy. Neraz pritom vznikla až groteskná situácia. Na stole predo mnou protižidovský článok a v kresielku pre hostí židovský prosebník".

${ }^{6}$ It is worth arguing whether we can speak about a "more unequivocal position" in the memoir narration, instead of a more precise term "unreliable", used to identify the narrator mostly in fiction texts. For example, Zuzana Fonioková writes about an unreliable narrator in autobiographical writing: “(...) zatímco ve fikci je spolehlivý autor tvůrcem nespolehlivého vyprávěče, $v$ autobiografii je autor sám nespolehlivým vyprávěčem (...). Když tedy čtenář odhalí nespolehlivost fikčního vypravěče a jak umně dílo vystavěl. Když čtenář zjistí, že má co do činení s nespolehlivým autorem, má to zpravidla opačný účinek" (“[...] Whereas in fiction, a reliable author creates an unreliable narrator, in an autobiography the author himself/herself is an unreliable narrator [...] Thus when a reader reveals unreliability of a narrator in fiction and how skilfully he/she constructed the work. When a reader finds out that he/she has to do with an unreliable author, it has an opposite impact as a rule"; Fonioková 2013: 126). 
literally in one day, and became a huge burden and a big social problem for the Slovak society (Hradská 2010: 102) ${ }^{7}$.

In that period, Urban was not the only writer (well-known mostly as a fiction writer) looking for new challenges of Slovak journalism in a new social context. I will mention Tido Gašpar ${ }^{8}$ who writes about this "purification" process the following: "We got rid of foreign rulers, magnates, land-lords, we got rid of Czech money exchangers and speculators. Now we are getting rid of the biggest suckers, prey seekers and parasites: Jews who robbed our poor folk most mercilessly" (Gašpar 1941: 60)9.

Gašpar inserts a category of "profit-vultures" (ziskožravci) into the same group of dangerous elements. In his argument, two categories deliberately "harming" a new state (Jews and "profit-vultures") overlap. $\mathrm{He}$ perceives both groups as residual elements of the previous period or of the capitalist past. This is why he encourages journalists to point at this harmful creatures belonging to the past and to cooperate with politicians. He sees the role of journalists in eliminating these enemies and in making them powerless. He places new social processes into a broader context, perceiving them as the beginning of a new social order.

Milo Urban joins the daily "Gardista" as the editor-in-chief in this kind of situation, as is clear from his article Po čo sme prišli? (What We Came For?) (Urban 1940b: 1-2). From his new position, he explains basic reasons of changing this periodical into a daily. He addresses readers in a rather general and simplified manner, and wishes to attract their attention and obtain their fidelity. He reassures them that a new daily will, in no case, endanger the "law of Slovak life" which is being formed; vice

\footnotetext{
7 “Rovnako ako v Nemecku aj na Slovensku arizácia židovského majetku a likvidácia židovských podnikov znamenali výrazný zásah do života jednotlivcov a v konečnom dôsledku aj celej židovskej komunity. Vlastníkov židovských podnikov štát legálne - arizovaním zbavil ich majetku, ktorý prešiel ,do krest’anských rúk'. Arizovaním zdecimovaní Židia zostali bez akýchkol'vek príjmov, doslova zo dňa na deň prišli o prácu, pre slovenskú spoločnost' sa stali obrovskou prít'ažou a vel'kým sociálnym problémom".

8 "Gašpar J. Tido (1893-1972) - writer, politician and diplomat. In 1940-1941, he was in diplomatic services of the Slovak Republic in Switzerland, from 1941 he was the director of the Propaganda Office and he actively spread official ideology" (Lukáč 1997: 524).

9 “Zbavili sme sa cudzích vládcov, magnátov, zemepánov, zbavili sme sa českých peňazomencov a ket’asov. Teraz sa zbavujeme najväčších vysávačov, koristníkov a cudzopasníkov: Židov, ktorí najbezohl'adnejšie olupovali náš úbohý l’ud".
} 
versa, its ambition is to contribute to new regulations. This task is sharply contrasted with the past:

Yes. To add a supplement to the law of Slovak life. That is why we came. We came to tell our Pharisees and Scribes that days of the old world were counted, that old liberal and capitalist way of thinking, old Talmudic morals injected into our public by Jews must recede to the truths of the new world even here under the Tatra mountains (Urban 1940b: $1-2)^{10}$.

He contrasts the old world that is about to finish with everything new and healthy "longing" to reach a new beginning that has already been announced. Urban presents the daily "Gardista" as an imaginary lighthouse which is to help people to get rid of a vicious circle of social and ideological prejudice. The common goal is the bright future that was announced.

Urban's introductory confrontation between the past and the future is a bit abstract but we are able to reveal in it signs of radicalism in expression. In this manner, journalism of the era creates an important parallel to the ambitions of power among new political establishment which tries, with the help of "laws", to exclude one part of citizens from the society". It is a paradox that leaders of the mentioned political establishment also publish their contributions in the same issue of the paper and on the same page as Milo Urban. A short article by Vojtech Tuka sees a daily "Gardista" (as a radical mediator of messages from the "battle field" against political and ideological opponents. His words are unequivocal, clear, convincing and do not try to hide anything. He announces a focused attack: "After three-month-long thorough reflections, preparations and convocations, a concentrated attack on old-fashioned and rusty remnants of the former

10 “Áno. Doplnit’ zákon slovenského života. Po to sme prišli. Prišli sme povedat’ našim farizejom a zákonníkom, že dni starého sveta sú už spočítané, že starý liberalisticko-kapitalistický spôsob myslenia, stará talmudistická morálka, naočkované do našej verejnosti Židmi, musí ustúpit' pravdám nového sveta aj tu pod Tatrami”.

${ }^{11}$ Just to add a relevant piece of information, on 3 September 1940, "z iniciatívy V. Tuku slovenský snem prijal zákon, ktorý splnomocnil vládu urobit’ všetko pre vylúčenie Židov z hospodárskeho a sociálneho života (9. september 1941). Vylúčenie Židov z politického života a obmedzenie ich vplyvu v hospodárskej oblasti priniesli už predchádzajúce zákonné normy" ("from the initiative of V. Tuka, Slovak parliament adopted a law which authorized the government to make everything in order to exclude Jews from economic and social life [9 September 1941]. Previous legal measures already excluded Jews from political life and reduced their influence in economic area"; Škvarna 2006: 154). 
Judeo-plutocratic and Czecho-democratic era. A march of achievers, of courageous, self-sacrificing and self-confident leading workers of national work that cannot be stopped" (Tuka 1940: 1) ${ }^{12}$. Alexander Mach ${ }^{13}$ also writes about a battle with "enemies" hiding in towns and villages on the same page of the paper. He encourages the whole editorial board of a new daily to become the closest press "collaborators" of Hlinka's Guard $(\mathrm{HG})^{14}$. He perceives this period as a key moment to change the society decisively, adapting it to new political conditions in the country. All changes in Slovakia, carried out so far with some problems, have to become more systematic thanks to this close cooperation: "The «Gardista» is published as a daily in times when the entire Hlinka's Guard makes appearance as an army of the Slovak National Socialism (...). Hundreds of sneaking enemies were hidden in every town and village. From now on, nothing will be done by chance" (Mach 1940: 1) ${ }^{15}$. He encourages all editors of the "Gardista" to remain in the position of an imaginary alert, and this is phrased as a hypothetical command for whole "modern" Slovak society. Following new rules, a new society is created in a totalitarian state with one political party (HSLS, Hlinka's Slovak Folk Party). This state functions under the protection of Nazi Germany, and its laws exclude Jews from economic and public life.

Notions such as change and development of Slovakia are also mentioned in Urban's following article published several days later. I add that

12 “Po trojmesačnom dôkladnom uvažovaní, prípravách, nástupe začne sa koncentrovaný útok na zastaralé a zahrdzavené pozostatky niekdajšej židoplutokratickej a čechodemokratickej doby. Nezadržatel'ný to pochod úderníkov, odvážnych, obetavých a sebavedomých predných robotníkov národnej práce".

13 "MACH, Alexander (1902-1980) - journalist and politician. He presented himself as a radical nationalistic journalist already during the First Republic (...) He also worked as a director of the Propaganda Office where he officially spread his anti-Czech and anti-Jewish attitudes. He, together with the Prime Minister V. Tuka, represented a pro-Nazi Germanophile wing among chairs of the HSL'S (Hlinka's Slovak Folk Party)" (Chmel 1997: 531-532).

14 "HLINKA'S GUARD - a semi-military organization active between 1938 and 1945 (...) After negotiations in Salzburg in July 1940, it completely got into hands of pro-German radicals. It carried out fight and security missions, guarded in labour camps, and participated in organizing deportations of Jewish citizens (25 March 1942)" (Škvarna 2006: 236).

15 “Gardista vychádza ako denník v časoch, ked” HG celá nastupuje ako vojsko slovenského národného socializmu (...) Každé mesto, každá dedina skrývala na stá potmehúdskych nepriatel'ov. Odteraz nič nebude zverené náhodne". 
the author published it under a pseudonym (Urban 1940a: 1). In this article, Urban, completely in accordance with previous ideologically biased statements, mentions his "own" familiarity with current changes in Slovak towns and villages. He defends the activity of political leaders whose effort changes, along with the outside image of Slovak places, "inside of Slovak person" ("vnútro slovenského človeka"). Using overstatements in language meaning, Urban makes connections between people and the external, material world. It reminds him of one large construction site charged with optimism. He expresses his hope to see a "new face of Slovak person" („,novú tvár slovenského človeka”) revealed in this mass effort, which can be considered a motif repeated in several articles. According to his words, Slovaks themselves comprehended a lot, and now they soberly judge social, political and ideological changes. He finds it important that nobody deliberately "harms" people. Namely, he writes:

Not disturbed by foreign influences, by incendiaries of various foreign agents, [one] comes to terms with oneself and one's environment. Only here and there, some poisoned intellectual or a Jew moves like a shadow near the wall to disappear then in the nearest gate. These are only shadows of the past. They feel that it is the end; that there is no place for them in this new, self-confident community of Slovak people (Urban 1940a: 1) ${ }^{16}$.

When foreseeing future destiny of citizens of the "new" Slovakia, Urban goes even further. In accordance with "shadows of the past" mentioned before, he speaks about a final removal of the harmful heritage from the past, about "eliminating various poisons injected into us which changed our mentality" (Urban 1940a: 1) 17. He characterizes as "wicked foreign propaganda" (Urban 1940a: 1) ${ }^{18}$ any voice raising doubts about the direction of a new community. At the same time, he is appealing to people's general sense of responsibility for the nation and state which is to change it into a self-confident group of people.

16 “Nevyrušovaný cudzími vplyvmi, podhuckávaním všelijakých cudzích agentov, vyrovnáva sa so sebou i so svojím prostredím. Iba tu-tam ak nejaký otrávený inteligent alebo Žid prešuchne sa ako tôňa popri stene, aby zmizol v najbližšej bráne. Sú to už len tône minulosti. Cítia, že je koniec, že v tomto novom, sebavedomom spoločenstve slovenských l'udí nemajú čo hl'adat".

17 “(...) vylúčení rozličných jedov, ktoré do nás naočkovali a ktoré zmenili celú našu mentalitu".

${ }^{18}$, ,...) prefíkanú cudziu propaganda”. 
The editor-in-chief, Milo Urban, also discusses this theme in other texts. We find a similar line of reasoning in a relatively long editorial summing up one-year activity of the daily "Gardista" (on this occasion, he evaluates changes of "modern" Slovakia that were imposed radically. He openly speaks about the times of "final counting" or about a decisive struggle between representatives of the "old" and the "new" worlds. In his opinion, all unpleasant incidents and partial failures were caused by intrigues of enemies, mostly posthumous children of previous regimes trying to destabilize some hesitant and conservative citizens. He is convinced that the chosen path of national development is the only right one; and it adheres to the truth. He refers to the article by the chief commander of Hlinka's Guard, Alexander Mach, published on the first page of the "Gardista" a year ago. Urban expresses his satisfaction with one-year activity of the periodical which has a key role in the "purification process" of Slovak society. With a similar zeal, he defends the most remarkable achievements of this period, although he also points at initial complications when introducing measures into the practice: "It is similar to Nuremberg laws or Jewish codex that we have recently introduced" (Urban 1940a: 1) ${ }^{19}$. He appreciates that they were adopted, although he realizes that the public had to be thoroughly prepared to accept them. The author does not mention games of power or political struggle in his article. He finds that the duel between the old and the new worlds is a spiritual struggle. Along this line of reasoning, he phrases ambitions of the entire editorial board to influence thinking of Slovaks. He writes: "We will help a Slovak person to get rid completely of the sick past, to free from nets of capitalist-liberalist and Judeo-Bolshevik opinions so that one obtains a new healthy National Socialist view of life and the world in cultural, political, economic and social issues" (Urban 1940a: 1$)^{20}$. In the final part of the article, he uses words about his hope in abstract better future not only for people in Slovakia but also in Europe; words that were repeated so frequently.

${ }^{19}$, „(...) Podobne je to aj s norimberskými zákonmi, resp. so Židovským kódexom, ktorý sme nedávno zaviedli”.

20 “(...) Budeme slovenskému človeku pomáhat', aby definitívne zhodil putá chorej minulosti, aby sa vymanil z osídiel kapitalistickoliberalistických i židobol'ševických náhl'adov a aby si v kultúrnych, politických, hospodárskych a sociálnych otázkach osvojil nový zdravý národnosocialistický pohl'ad na život a na svet”. 
Urban marginally deals with the so-called "Jewish question" in the third part of his memoirs ${ }^{21}$. He is cautious when reasoning (as if he did not want to explain it). He openly declares his subjective "ignorance" (in the past) about the state of the problem and its tragic aspects. He attributes key competences and responsibilities to political elites of the era, although he, paradoxically, also postulates a question about the lack of knowledge on their part that would diminish their guilt and responsibility at least partially. This approach is also present when defending his team of editors:

Jewish question [bold K.Cs.]. We opened it quite cautiously, hesitantly and moderately but Germans insisted and Tuka got stampeded. In order to show Hitler how brave he is, he said to himself that he would even outdo his Nuremberg laws. Whether he outdid them, I do not know until today because I was not interested in similar laws but even a blind person could see that he rushed a lot (...) crowds of scared Jews [bold K.Cs.] were summoned to gathering camps first at home and after some time in the Reich (...) No. We did not take this question tragically at that time. None of us could have had and had any clue (it was 1941) about what would come out of it (Urban 1994: 82) ${ }^{22}$.

We could consider Urban's fatally simplified and a bit infantile statements as a conclusion of his reasoning. He repeated words about

${ }^{21}$ This theme in the context of Urban's memoirs was only researched marginally by Milan Hamada after 1989. V. Hamada 1995: 123-128, 2011. Pavol Parenička (1955: 132-142), brings information on Urban's activities as an editor and journalist, without analyzing or judging them, and without comparing them with his memoirs. Barbara Suchon-Chmiel (2007) discusses Urban's journalism and memoirs as a separate part of his activities.

22 “Židovská otázka. Načínali sme ju dost’ opatrne, váhavo i mierne, ale Nemci naliehali a Tuka sa plašil. Aby ukázal Hitlerovi, aký je on vitúz, povedal si, že prekoná i jeho norimberské zákony. Či ich naozaj prekonal, neviem dodnes, lebo som sa o podobné zákony nezaujímal, ale že sa vel'mi ponáhl’al, mohol vidiet' i slepý (...) zástupy vydesených Židov rukovali do sústred'ovacích táborov najprv doma a po nejakom čase do ríše (...) Nie. Vtedy sme ešte túto otázku nebrali tragicky. Nik z nás nemohol mat’ a nemal ani poňatia (písal sa ešte rok 1941), čo z toho bude".

Another historical paradox in the development of Slovakia during WW II coincides with the situation described in Urban's memoirs. Deportations of Jews from Slovakia into German concentration camps began on 25 March 1942. "Slovakia was the first autonomous state that deported a large part of its own Jews. It was, at the same time, the first state that stopped deportations in October 1942 after the news on exterminating Jews in concentration camps (...) Deportation only resumed in October 1944 after German army arrived in Slovakia". (“Slovensko bolo prvým samostatným štátom, ktorý odsunul vel'kú čast' svojich Židov. Zároveň bol prvým štátom, ktorý deportácie po správach o vyhladzovaní Židov v koncentračných táboroch v októbri 1942 zastavil (...) Deportácie sa obnovili až v októbri 1944 po príchode nemeckej armády na Slovensko"; Škvarna 2006: 155). 
a "beautiful" future of Jews in some kind of a new, not clearly defined space (in some kind of gubernia). According to Urban, there were some Jews, who also believed in this "vision". A completely different part in his memoir fragments confirms his trust in civilization progress of Hitler's Germany, softly introduced by statements about his supposed naïveté and social indifference. In the process of remembering the past, Urban uses this attitude as a central element of his visible disavowal of everything negative that he experienced as the editor-in-chief of the daily, which had a clear ideological and racial orientation. His words prove this: "Germans are great organizers. They already cracked harder nuts. That they would hurt Jews for no reason? I was - as one says slow on the uptake; it took me long to realize fully that horrible news about Jews could be true" (Urban 1994: 83-84)23. The author moves the semantic meaning in this passage more into his personal area. Thus Milo Urban creates a self-portrait different from the image of a reserved, a bit ignorant and non-heroic editor-in-chief of the "Gardista", who also completely lacked information. In this position, the subject of the author is a silent and patient helper of persecuted Jews. He is not very successful in this role either, although the following kind of statements helped him in the lawsuit after the war:

Only in the fourth case - and this thanks to favourable circumstances - I managed to solve a rather difficult case. Guard members in Trenčín were gathering Jews for the last transports (...) And my visitor? I do not remember how but he survived chasing after Jews. What is more, he did not hesitate to present a testimony in my favour when they tried me in court after the war (Urban 1994: 85-86) ${ }^{24}$.

Urban's innocent textual statement that he did not know about concentration (extermination) camps while he was the editor-in-chief represents a symbolical climax of his memoirs. The author makes our impression from this short but extremely important theme even stronger when he admits:

23 “(...) Nemci sú skvelí organizátori. Oni už rozluskli tvrdšie oriešky. Že by Židom nič pre nič chceli ubližovat? (...) Mal som - ako sa vraví - dlhé vedenie; dlho mi trvalo, kým som si naplno uvedomil, že hrôzostrašné chýry o Židoch môžu byt' pravdivé".

24 “(...) Až v štvrtom prípade - aj to zásluhou priaznivých okolností - podarilo sa mi vybavit' dost' ošemetný prípad. Gardisti v Trenčíne zbierali Židov do posledných transportov (...) A môj návštevník? Už neviem ako, ale všetky pohony na Židov v zdraví prežil. Ba čo viac, ked' ma po vojne súdili, neváhal svedčit' v môj prospech". 
Was it I who raised Hitler and his regime on feet? Was it I who helped him to put on boots? Was it I who underwent his carefree marching? Was it I who closed various agreements and pacts with him? That pushed Europe into this bloody cataclysm? No. I only felt fear and... (Urban 1994: 126)

However, this more submissive perception in the third part of memoirs is challenged by author's journalism from the war period, as well as by his responsibility for the contents of respective issues of the "Gardista" 26 . I will conclude my presentation of Urban's memoir and journalistic "touches" with the theme of the Holocaust by discussing the article Otvorené rany (Open Wounds) from November 1942, which is (only) seemingly not related to this problem. From the very beginning, the author works with the image of "enemies" of the Slovak independence whom he finds in ethnically or nationally mixed families. He focuses on Hungarian and Czech national influence: "Two mentioned relations though - Hungarian and Czech ones - were mass phenomena stimulated from the above with an obvious intention to direct our blood to foreign basins" (Urban 1942: 1) ${ }^{27}$. The author relates ideas about "betrayals" in family ties to the tragic destiny of the national community, and proposes to take some steps. Urban finds a solution to this "appalling" injustice in "just" and rational measures (control) in the society that would, this way, avoid its end. In Urban's words,

when churches have the right to defend themselves against mixed marriages, and we fully understand and acknowledge this right, when various viewpoints get applied, our nation must also reach for this right and prevent forming other wounds at least in these areas (...) if we had controlled love life by a national order, we could have been spared from numerous disappointments (Urban 1942: 1) ${ }^{28}$.

25 “(...) Či ja som postavil Hitlera a jeho režim na nohy? Či ja som mu pomáhal obúvat’ čižmy? Či ja som trpel jeho bezočivé pochody? Či ja som uzatváral s ním všelijaké dohody a pakty?, ktoré sotili Európu do tejto krvavej skazy? Nie. Ja som sa len bál a...".

${ }^{26} \mathrm{I}$ have in mind numerous articles published in the daily "Gardista" between the end of 1940 and the beginning of 1945 which comment on the so-called "Jewish question" in Slovakia and Europe in an ideologically and racially extreme manner. Milo Urban works as the editor-in-chief of this daily during the entire period.

27 “(...) V uvedených dvoch vzt'ahoch však - mad’arskom a českom - išlo o hromadné zjavy, podporované zhora so zrejmým úmyslom odvádzat' našu krv do cudzích korýt".

28 “(...) ked’ cirkvi majú právo bránit’ sa proti miešaným manželstvám a my toto právo plne chápeme a uznávame, ked' okolo nás uplatňujú sa hl’adiská, aj náš národ musí siahnut' po takomto práve a zamedzit' tvoreniu d’alších rán tohto druhu aspoň v týchto oblastiach (...) 
One might have an impression that this article avoids "solving" the "Jewish question" but it is a fallacy since it is quite similar to a text entitled Židovská otázka a nový manželský zákon v Mad'arsku (Jewish Question and a New Marriage Law in Hungary) (Židovská otázka... 1941: 7). In this article, editors comment on attempts to assimilate the Jewish community in Hungary through mixed marriages with non-Jewish citizens. The article describes a rising tendency to create this kind of family bonds. It considers the decision of the Hungarian Minister of Justice to prohibit these marriages worth following. A final quote is rather interesting: "The last word in the Hungarian Jewish question has not been said by this but the law is in fact an important step forwards on the way to a final solution, which can only be seen in moving Jews out of the country" (Židovská otázka ... 1941: 7) ${ }^{29}$. We could find more similarities and hidden connections between Urban's own articles and other texts, for which he was responsible as the editor-in-chief.

By stating this, I am about to conclude my multiple comparisons of different genres and ways of writing by one author. At the beginning of my article, I stated that all versions of his writing are interconnected by a widely defined theme of the Holocaust. In all other aspects, however, we find significant differences. In his memoirs, Urban's presentation of one of the major crises of the $20^{\text {th }}$ century is linguistically neutral, impersonal and rather naive. He makes us believe that he was a fearful and powerless victim of historical events, who knew nothing about tragic facts (in this case, about the solution of the Jewish question) in spite of being the editor-in-chief of the daily "Gardista". This sort of gesture is related to a remarkable time distance from those historical events since the third book of Urban's memoirs only originated in the 1960s. His journalistic texts from the period of the Second World War provide us with a completely different image of the author, whose language is subjective, radical, fanatical, unequivocal and ideologically determined. Urban himself is an adherent of an extreme ways of "solving" the Jewish question; and considers it just and necessary, as numerous quotations of his journalism from this period used in my article wish to

keby sme boli usmerňovali aj jej l'úbostný život národným príkazom, mohli sme si ušetrit' nejedno sklamanie".

29 “(...) Posledné slovo v mad’arskej židovskej otázke ešte nie je povedané týmto, ale zákon je predsa dôležitý krok vopred na ceste ku konečnému riešeniu, ktoré možno hl'adat' len vo vyst'ahovaní Židov z krajiny”. 
prove. To enable readers to see the frequency and character of Milo Urban's "touches" with the theme of the Holocaust and its "solution", I emphasize some words and expressions in my article, writing them in bold. Contrasted to memoirs, journalistic texts offer us a burning sensation from the tragic era that has to be refuted ${ }^{30}$. Thus the article, besides covering some aspects of the historical tragedy, reveals an individual tragedy of one personality's life.

\section{Literature}

Bartl J., Čičaj V., Kohútová M., Letz R., Segeš V. (eds), 2006, Lexikón slovenských dejín, Bratislava.

Csiba K., 2014a, Kalendárium života a diela, in: M. Urban, Živý bič, Bratislava, pp. 336-337

Csiba K., 2014b, Privátne - verejné - autobiografické (v memoároch a publicistike Mila Urbana, Jána Smreka, Jána Poničana, Tida J. Gašpara), Bratislava.

Chmel R. (ed.), 1997, Slovenská otázka v 20. Storočí, Bratislava.

Fonioková Z., 2013, Nespolehlivost autora: Otázka vypravěčské nespolehlivosti

$v$ autobiografických textech na př́kladu knihy Montauk, "World literature studies" Vol. 22, No. 1, pp. 124-132.

Gašpar J.T., 1941, Ziskožravci, Bratislava.

Hamada M., 1995, K světonazoru Mila Urbana, in: Biografické studie 22, Martin.

Hamada M., 2011, Kritické komentáře. Prvý zväzok, Levice.

Hradská K., 2010, Tragédia slovenských Židov, in: W. Benz, Holokaust, Trenčín, pp. $100-119$.

Lukáč P., 1997, Bibliografické charakteristiky autorov a bibliografické poznámky, in: Slovenská otázka v 20. storočí, ed. R. Chmel, Bratislava.

Mach A., 1940, Do pohotovosti!, "Gardista” Vol. 2, 01.11., p. 1.

Parenička P., 1995, Milo Urban ako redaktor a novinár, in: Biografické studie 22, Martin.

Suchoń-Chmiel B., 2007, Spóźnione spowiedzi, czyli autobiografie uwikłanych whistorii pisarzy stonackich XX wieku, Kraków.

Škvarna D. et al. (eds), 2006, Lexikón slovenských dejín, Bratislava.

Tuka V., 1940, Gardistovi na cestu, "Gardista" Vol. 2, 01.11., p. 1.

[Urban M.] mu-, 1940a, Slovensko sa mení, "Gardista” Vol 2, 06.11., p. 1.

Urban M., 1940b, Po čo sme prišli?, "Gardista” Vol. 2, 01.11., pp. 1-2.

Urban M., 1941, Po roku, "Gardista" Vol. 3, 01.11., p. 1.

Urban M., 1942, Otvorené rany, "Gardista” Vol. 4, 22.11., p. 1.

Urban M., 1994, Na brehu krvavej rieky, Bratislava.

Židovská otázka a nový manželský zákon v Mad'arsku. Kritický nemecký hlas o riešení židovskej otázky v Mad'arsku, 1941, "Gardista”, Vol. 3, 01.11., p. 7.

\footnotetext{
${ }^{30}$ For more details, v. my monograph: Csiba 2014b.
} 